\title{
CIRILO VILLAVERDE, FUNDADOR
}

\author{
POR \\ ANTONIO BENITEZ-ROJO \\ Amherst College
}

De todos los textos de Cirilo Villaverde, el que más me interesa es el titulado Excursión a Vueltabajo. Y no es que Cecilia Valdés carezca de importancia para mí. Al contrario, pienso que es la primera de las grandes novelas caribeñas. Ocurre, sin embargo, que en 1882, fecha de su publicación en Nueva York, su texto es bastante previsible. Abolida ya la esclavitud, Cecilia Valdés tiene mucho de novela histórica y, por tanto, mucho de reflexión, mucho de interpretación de una época ya vencida y debatida. Las dos partes que componen Excursión a Vueltabajo son, a todas luces, otra cosa. No sólo porque sus textos respectivos se refieren a una actualidad, sino sobre todo porque ambos son publicados en el momento de emergencia de los discursos nacionales, entre ellos los que corresponden a la geografía, a las ciencias naturales, a la economía, a las ciencias sociales, a la lexicografía, a la literatura. Todos estos incipientes discursos tienen como propósito hablar de lo cubano o, si se quiere, des-cubrir lo cubano. Cada uno de ellos, desde su especificidad disciplinaria, se inserta históricamente en un espacio privilegiado, puesto que son los primeros que de manera autoconsciente intentan definir lo cubano. Se trata de discursos fundadores, de discursos que resultan de una manipulación autoral de la realidad de Cuba a partir de un sentimiento patriótico-nacional. No tengo reparo alguno en designar «fundadores» a gentes como Arango y Parreño, Varela, Heredia, Poey, Pichardo, la Avellaneda y, claro, Saco, Luz y Caballero y todo el grupo de Delmonte desde Manzano hasta Suárez y Romero. Pero, entre todos ellos, el que leo con mayor interés literario es Cirilo Villaverde, más que nada porque, en mi opinión, nadie igualó su Excursión a Vueltabajo en tanto texto que se propone relatar la búsqueda de lo cubano. Expongo a continuación mi lectura de este texto, o mejor, 
de estos dos textos, ya que el libro armado por Villaverde en 1891 comprende las narraciones de dos viajes a esta región de Cuba, cada una de ellas publicada previamente por separado. El primer relato apareció, en 1838, en El Album; el segundo, en 1842, en el Faro Industrial de La Habana.

¿Cuáles son los objetivos aparentes de estos viajes de Villaverde? Visitar el poblado de San Diego de Núñez, lugar de su nacimiento (1812). Así, desde el comienzo, ambas excursiones a Vueltabajo se nos ofrecen como «viajes a los orígenes». La fecha exacta de la primera excursión se desconoce. Si tomamos como buena la información que suministra el personaje principal del relato, un Patriarca, el viaje ocurrió en 1831. Por esa época Villaverde estudiaba leyes en el colegio de San Carlos y tal vez ni siquiera soñara con ser algún día un escritor. Podemos presumir que el viaje se produjo en sus vacaciones de estudiante —el texto nos dice que es verano- y que, siguiendo la costumbre de la época, tomó notas del mismo en su diario. Años más tarde, estos apuntes o recuerdos servirían de material para elaborar su narración. Antes no hubiera sido posible, al parecer, puesto que en Cuba la narrativa se inicia en 1837 con la pı blicación de «Matanzas y Yumurín, de Ramón de Palma, y cuatro cuentos del propio Villaverde, que, más que piezas acabadas, pueden tomarse como ejercicios. Asiduo ya a las tertulias de Domingo Delmonte, su novela breve El espetón de oro (1838) —el primer libro de la narrativa cubana- le granjea el reconocimiento de la flamante intelligentsia habanera. Es entonces, sabiéndose ya un escritor, cuando Villaverde experimenta la necesidad de legitimar su cubanía y, al mismo tiempo, la cubanía de su literatura. Le es preciso, pues, escribir un texto que, irrevocablemente, se signifique a sí mismo y lo signifique a él como cubano. Se comprende mejor esta doble necesidad si se recuerda que el círculo de Delmonte, a instancias de Delmonte, se propone fundar con toda deliberación una literatura nacional que se exprese a través de todos los géneros posibles; esto es, poesía, teatro, ensayo, cuadro de costumbres, cuento, novela, autobiografía, artículo, crónica y crítica literaria, y todo ello lanzado por revistas editadas por miembros del grupo. Es lo que he llamado en otro lugar la Conspiración del Texto, ya que esta literatura nacional debe referirse de una manera u otra a las ideas reformistas anticipadas por Saco, Luz y Caballero y el propio Delmonte. Es en este contexto cuando aparece en El Album la primera «Excursión a la Vueltabajo». Así, su texto debe verse como un viaje hacia «orígenes» ya preconcebidos y discutidos dentro del círculo de Delmonte.

Villaverde comienza su relato sin dar cuenta de su partida de La Habana. El discurso lo toma ya, de repente, en la escabrosa región de Vueltabajo, 
a unos cien kilómetros de la capital. Desde el inicio, el «autor» se propone como «descubridor». Anda a caballo por parajes innombrados; nos habla de «salvajes formas» que carecen de «un nombre bastante popular por donde vengan a ser conocidas», e incluso de «un punto en que un pintor pudiera fijar el centro de la vasta perspectiva que abarcan las líneas de este mi bosquejo». Sin embargo, Villaverde no se atribuye exclusivamente el rol de viajero a los orígenes; da fe de que por allí también ha pasado el naturalista Felipe Poey nombrando «salvajes formas» para su Geografía de Cuba, publicada en 1836. Tal información resulta valiosa no sólo porque permite fechar la redacción del texto entre 1836 y 1838 , sino sobre todo porque afirma que la empresa descubridora es de índole corporativa; en ella participa el grupo de Delmonte en pleno - Poey era uno de sus más distinguidos miembros-, es decir, la matriz logocéntrica que da a luz los discursos nacionales. Es esta fuente del Nuevo Conocimiento la que ha investido a Villaverde de poderes «auténticos» para que su viaje tenga buen término. Así, llegado a este punto, mi lectura de «Excursión a la Vueltabajo" se acerca a la de un cuento maravilloso o mito, donde Villaverde asume el papel de caballero de una orden prestigiosa que le ha encomendado la búsqueda del «tesoro difícil de obtener»: lo cubano.

En efecto, el carácter legendario de la narración se evidencia ya en los mismos comienzos del texto: «De suerte que apenas se pasa la Tuba, último terreno igual y cultivado de cañas, lindero puesto por la naturaleza entre éstos y los quebrados de improviso, los ojos del caminante se pierden con tristeza y con melancólico vagar al través de los troncos de los gigantescos árboles, las enredaderas de tibisí, los declives de los promontorios...» La Tumba, pues, es el Primer Umbral; separa a la naturaleza domesticada de la salvaje; al camino recto, del laberinto; a la luz, de las sombras. Más allá de esta Puerta —o primera iniciación del Héroe, según la doble referencia que suele portar este signo-, el tiempo se detiene, puesto que se está en Ultra-Tumba. Repárese en la connotación telúrica y a la vez subterránea y antónima que porta el nombre Vuelta Abajo.

Concluidos algunos pasajes descriptivos, aparece un negro en calidad de personaje mágico. Su doble naturaleza hermética — benéfica/maléficaes confirmada en seguida por Villaverde: «Su fisonomía, examinada despacio, era la más alegre que se ha visto: los ojos redondos y bailadores, la frente ancha, los carrillos prominentes, el color atezado; todo esto sujeto a transformarse fácilmente en un rostro severo y duro». Este negro mercurial que anda por los senderos del monte con un cayado, ocupándose en asuntos de compraventa de mercancías, es en realidad una Prueba. Villaverde sale bien del paso al tratarlo con amabilidad y al darle una moneda de plata. A cambio, el Hermes negro, o si se quiere, Elegua —orisha, 
afrocubano que domina los caminos, las puertas y las transiciones-, lo conduce ante el Segundo Umbral, una taberna llamada San Salvador. La barrera que corta el camino está defendida, como es de suponer, por un Guardián. En la narración, tal personaje es caracterizado como un «guardiero», esclavo viejo dedicado a los menesteres de abrir y cerrar la talanquera; su aspecto es repulsivo y nos remite al orisha de las enfermedades, Babalú-Ayé: «salió a abrirnos embarrado el rostro de ceniza, descubiertas las espaldas y el vientre, en el cual se alzaba a manera de verruga un ombligo disforme, y cojeando de un pie cuya canilla se mostraba envuelta en muchos trapajos». El carácter mágico de la situación es subrayado por Villaverde: «Mi compañero de viaje se le acercó para saludarlo; yo pasé de largo, porque ya divisaba la taberna de San Salvador. Al entrar en el colgadizo de ella, se me presentó el mismo mozo negro de la canasta en el estribo derecho para sujetármelo mientras me apeaba. Esta aparición repentina, cuando yo lo había dejado conversando media legua atrás, no pudo menos de sorprenderme.»

En la taberna, Villaverde conoce a un arriero, con quien almuerza y sostiene una larga conversación sobre los posibles caminos a seguir. Pero este nuevo compañero de viaje, como veremos en seguida, es un Falso Héroe dentro de la perspectiva ideológica del círculo de Delmonte. El carácter negativo que tomará el personaje - es decir, su insuficiencia en tanto buscador de lo cubano- se debe a su antagonismo hacia los negros, sobre todo hacia los cimarrones. Al arriero no le bastará ser guajiro, como destaca Villaverde, para descubrir lo cubano, pues tal espacio se propone como un «centro» reconciliador de oposiciones raciales. En efecto, al llegar al Tercer Umbral —nombrado potrero del Cuzco-, el arriero maltrata a un segundo negro guardiero que cuida la rústica puerta de trancas. El altercado se produce al hallar el arriero, en la choza del negro, objetos y armas dejadas allí por un cimarrón la noche anterior. En esta ocasión el Guardián es caracterizado como el orisha Changó: «vestido con camisa encarnada de bayeta, gorro de lo mismo en la cabeza en forma de montera a la española y una especie de sandalias de cuero; el cual, alegre y vivaz como una candela, abrió precipitadamente haciendo mucho ruido con las trancas». En el interior de la choza hay güiros de aguardiente, carne de caza, thi hoguera y un venablo con punta de acero. El color rojo, la forma peculiar del gorro, el carácter alegre y vivaz del negro, la candela, la bebidă alcohólica y las armas son atributos de este orisha guerrero, cazador, bebedor y mujeriego que suele ser implacable con sus enemigos. Es interesante la identificación del guardiero con el cimarrón, ya que aquél asume la naturaleza guerrera y montaraz de éste. Así, al ser agredido por el arriero, su «doble» lo habrá de esperar en la Peña Blanca - la Prueba más 
terrible que aguarda al viajero de Ultra-Tumba, la Calavera, la Muerteen horas de la noche para consumar su venganza.

Villaverde, al proteger al negro de los golpes del arriero, gana su favor, y éste le murmura al oído que no tome el camino que pasa junto a la Peña Blanca. El arriero se burla de la recomendación a Villaverde y es hallado muerto en el lugar a la mañana siguiente. Tal es el precio de excluir a los negros del espacio de lo cubano. La referencia a la rebelión de esclavos es clara, sobre todo si se tiene en cuenta que el aumento que exponía el círculo reformista para suprimir la trata y eventualmente la esclavitud era, precisamente, el paralelo de la situación cubana con la de la colonia francesa de Saint-Dominique, que había desembocado en la guerra y en la fundación de una república negra con el nombre de Haití. La moraleja de este incidente no puede ser más directa y sencilla: si se sigue esclavizando a los negros, éstos tomarán venganza sobre nosotros; por tanto, si queremos construir una nación cubana hay que contar con la alianza de ellos. Este juicio, por supuesto, no excluía la presencia del prejuicio racial ni de la segregación; se refería únicamente al reconocimiento de que el negro era también y a contrapelo un componente sociocultural de la nacionalidad.

Luego de este significativo pasaje, Villaverde llega por fin a San Diego de Núñez, esto es, a los «orígenes». Pero, como es sabido, no hay orígenes estables ni en el tiempo ni en el espacio. De modo que Villaverde se ve forzado, como el que pela una cebolla o abre un juego de cajas chinas, a narrar los sucesivos «orígenes» de San Diego de Núñez. El primero de ellos, naturalmente, corresponde al poblado tal cual lo encuentra el viajero en la década de 1830 . Se trata de un caserío de una sola calle, localizado en la primera estribación de la Cordillera de los Organos, que Villaverde llama la Sierra Madre. Económicamente, San Diego de Núñez no responde a la costa norte de la provincia, hacia la cual mira. Allí, muy próximos, se hallan los puertos azucareros de Bahía Honda y Cabañas; esto es, puertos de la llamada «Cuba grande», la Cuba del ingenio de azúcar, la Cuba esclavista que mira hacia los mercados de exportación, hacia afuera. Pero, a pesar de esta proximidad, el poblado se ha mantenido fuera de la «Cuba grande», subsistiendo precariamente bajo una economía ganadera de corrales y conectándose a La Habana por el llamado Camino Real. San Diego de Núñez se inscribe, pues, en la «Cuba chiquita», la Cuba preazucarera que mira hacia la tierra y hacia los primeros criollos. Fue de esta «Cuba chiquita» de la que surgió la «Cuba grande», como ilustra muy bien Villaverde: «Cuando se empezaron a fomentar los quince ingenios y veinte y dos cafetales que hoy componen la riqueza del Partido, bien pudo creerse que el pueblo progresara..., pero como poco después cada una se erigió en una población aparte con su jurisdicción civil y política, con sus tiendas 
provistas de todo lo necesario a la vida, con talleres de todos los oficios; hasta de aquellos meramente de lujo, como sastrerías y zapaterías, médicos, boticas y oratorio donde el párroco o cura hiciese oír la palabra de Dios; ya no necesitaron del pueblo para maldita la cosa, y lo dejaron abandonado a su propio destino.» De esta manera, San Diego de Núñez provee una puerta ideal para pasar de «orígenes» superficiales a otros más profundos, y de éstos al espacio adámico de la Primera Posesión, como se verá en seguida.

A un extremo de San Diego de Núñez quedan las ruinas de una gran casa de cedro, que «llaman grande los naturales»; frente a ella aún quedan en pie una cruz de quiebrahacha. La Casa Grande fue la primera vivienda del lugar. Allí vivió un personaje de trazas bíblicas que Villaverde denomina «el patriarca», y que sin otros títulos de propiedad de la tierra que la hazaña de desmontarla y fomentarla, engendró allí una vastísima familia de pobladores. La decadencia y la final disolución del clan es explicada por Villaverde: «Cuando se empezaron a casar unos con otros, a entroncarse y entrelazarse una misma familia, conocieron la necesidad de dividirse y la amargura de la separación. De este modo, esta tribu de Jacob comenzó a derramarse por las sierras, formando varias familias.» Y prosigue Villaverde: «De entre ellos los hubo, no obstante, que más sabihondos... se metieron a pleitistas, es decir, a formadores de la testamentaría, para cuyo fin vinieron a la capital... Retardándose de día en día la divisoria, el fallo que debería señalar a cada uno lo que fuese suyo, viéronse forzados a echar garra de lo primero que se les vino a las manos sin cuidarse de escrituras ni títulos y a meterse en un bohío a vivir... Para subvenir los costos y costas de la ponderada testamentaría hubo que poner en público pregón yo no sé qué número de caballerías, única moneda con que podían satisfacer..., vendían a cuantos compradores se presentaban; cada uno procuraba tomar la mejor porción; al cabo, vendido más de lo que tenían, fácil es adivinar la zalagarda que se armó... No parece sino que la maldición del Señor, hablando en el estilo solemne de la Escritura, había caído sobre las cabezas de esta tribu escogida.» Y concluye refiriéndose a los plantadores de azúcar y café: «Otras tribus, otras familias, otros hombres, han venido a poblar, a allanar el terreno y destruir los montes encima de los cuales tantas veces con los pájaros del bosque celebraron la llegada de la luz...»

Tal es la versión que ofrece Villaverde de los «orígenes»: una suerte de gens mítica y preplantadora que vivía de los frutos de la tierra en completa armonía con la naturaleza. Su derecho natural de posesión está significado por la cruz clavada en la tierra; el puntal, indicando la relación patriarcal de filiación; el travesaño, la relación horizontal de colaboración 
económica que une a la familia extendida. Bajo estos ejes está la tierra, una e indivisible. La Casa Grande es el espacio de lo cubano; es el arca bíblica de cedro construida por el Patriarca para la «tribu escogida». Este espacio precede al de las Diferencias, puesto que la tribu es una, la casa es una, la cruz es una, la tierra es una, la naturaleza es una y todo encaja entre sí con la armonía expresada por el Logos. El Castigo ocurre por la codicia de los que quisieron dividir y diferenciar la Patria en su provecho; entonces sobreviene la Expulsión, dictada por el Patriarca/Creador que vela desde los cielos. La Habana es Babilonia; allí se vive en la confusión. La tribu ha acudido a ella en busca de un procedimiento jurídico que «legalice» la división del legado patriarcal. Pero la ley de La Habana no es la Ley, sino una sarta de retorcidos embustes que se vuelven contra la tribu. Al final, los plantadores esclavistas de La Habana se apropian del legado y la tribu es dispersada.

El segundo paso de Villaverde dentro de los «orígenes» es visitar a un sobreviviente de la tribu. Villaverde también lo llama «patriarca», pero se trata de un anciano ciego —esto es, simbólicamente castrado-guiado por un perro que se está volviendo ciego. El encuentro tiene una doble función. En primer lugar, Villaverde es «reconocido» por el patriarca como «heredero» de lo cubano: «Levantó la cabeza, clavó sus ojos blancos y sin luz en los míos... - No, no me lo digas. Yo sé quién eres... - ¡Dame un abrazo, camará! Yo, que te vi nacer, que te cargué tantas veces en estos br: zos ahora flacos y débiles, que te vi jugar con mi difunto hijo...» En segundo término, gracias a este encuentro, Villaverde experimenta lo cubano. El patriarca se hace conducir por él a una altura desde la cual se divisa todo el lugar. Una vez allí, Villaverde enumera los poblados de los alrededores, las sierras y bosques, los ríos y los caminos, el cielo y el mar. Desde el centro de lo cubano, toma posesión de lo cubano, que es todo aquello, y también la mujer: «En esto sentimos la algazara y ruido que hacían las muchachas corriendo por los matorrales y veredas... El limpio en que el viejo y yo estábamos hablando, era un círculo bastante espacioso; así que el apareamiento repentino de aquellas cabezas, coronadas de flores, de entre las maniguas ásperas del potrero, llenas de guizazos sus ropas, arañadas sus caras de las espinas, no pudo menos de arrancarme un grito de alegría... Pero es lo bueno que sucias y llenas las bocas de las más de guayabas y otras frutillas del campo, como pitajayas y avellanos, producían un ruido tan desapacible, que las reduje echándoles en rostro su golosina... Animados de humor tan placentero, mujeres, hombres y perros, bajamos a las casas... Entramos en la población a la hora de encender las velas..., lo que pudimos observar desde las ruinas de la (Casa) Grande..., allí repartiendo las frutas que en los pañuelos habían quedado.» 
De este modo, Villaverde se inscribe en la «tribu escogida», ocupando el lugar del primogénito del Patriarca; toda la antigua hacienda le pertenece - mujeres, hombres, razas, árboles, frutas, animales--; todo es Naturaleza Cubana, la cual alcanza a poseer tras un «legítimo» acto de fundación. El resto del relato puede leerse como una coda. Más que nada, le sirve para narrar un incidente donde un negro esclavo de «recios miembros, lucientes carnes y encendidos ojos, hábil cual un pez», salva a un «guajiro» blanco de ahogarse en un río. El viaje termina con la visita de despedida al patriarca, ya al borde de la muerte al saber que su perro ha comenzado a perder la vista.

No es posible comentar aquí la segunda «Excursión a la Vueltabajo». En todo caso, se trata de un relato más extenso y detallado que el que hemos visto, pero el objetivo y el resultado son los mismos. No obstante, la necesidad de realizar un segundo viaje a los «orígenes» habla de la imposibilidad real del viajero de alcanzar la meta. Escribir de lo cubano, pues, es escribir de la búsqueda de lo cubano; revisitar una y otra vez los distintos caminos que conducen a su centro imposible. Para Villaverde - también para Carpentier en su Viaje a la semilla -, tal centro es la Casa Fugitiva, siempre en tránsito de desaparecer. Así, cada visita es un acto fallido que se intenta legitimar por la ficción. 